\title{
The Phenotypic and Pathological Features of Prune-Belly Syndrome
}

\section{Prune-Belly Sendromunda Fenotipik ve Patolojik Özellikler}

\author{
Davut ŞAHIN, Handan ÇETINER, Nermin KOÇ \\ Department of Pathology, Zeynep Kamil Women's and Children's Diseases Hospital, ISTANBUL, TURKEY
}

\begin{abstract}
Objective: Prune-belly syndrome is a rare congenital disorder characterized by musculature deficiency in the abdominal wall, lower urinary tract obstruction, other urinary tract anomalies, and bilateral cryptorchidism. The syndrome is commonly associated with pulmonary, skeletal, cardiac, and gastrointestinal defects. Over $95 \%$ of patients are male. Urinary tract disease is the major prognostic factor with the complications of pulmonary hypoplasia and end stage renal disease. The aim of this study was to determine phenotypic and pathologicalfeatures of fetuses with this syndrome.
\end{abstract}

Material and Method: Six fetuses with prune-belly syndrome were evaluated by postmortem pathological investigation. Characteristic features of the fetuses with this syndrome as well as additional anomalies were evaluated.

Results: Five fetuses were male while one was female. Gestational age ranged from 15 to 22 weeks. A urethral pathology that prevented urinary outflow from the bladder was present in all cases. Marked bladder distension with atrophy of the bladder smooth muscle and abdominal distension with muscular atrophy were also seen in all. Crypto-orchidism, Potter face, pes equinovarus, pulmonary hypoplasia and obstructive renal dysplasia were among the additional noteworthy anomalies.

Conclusion: The pathogenesis of prune-belly syndrome is controversial. More studies are required on the inheritance, etiology and pathogenesis of the prune belly syndrome. Factors affecting the bilaminar and trilaminar germ layer during early 2-3. embryonic week may be considered to explain the pathogenesis of the anomalies seen with this syndrome.

Key Words: Prune-belly syndrome, Uretral obstruction, Urinary tract anomalies, Fetus, Fetal pathology

\begin{abstract}
ÖZ
Amaç: Prune-belly sendromu nadir bir konjenital hastalık olup, abdomen duvarı kaslarında defekt, alt üriner traktüs obstrüksiyonu, diğer üriner anomaliler ve bilateral kriptorşitizm ile karakterizedir. Sendroma sıklıkla akciğer, iskelet, kalp ve gastrointestinal sistem (GIS) defektleri eşlik eder. Hastaların \%95’ten fazlası erkektir. Üriner trakt hastalıkları majör prognostik faktör olup pulmoner hipoplazi ve son evre böbrek yetmezliği gibi komplikasyonlara neden olabilirler. $\mathrm{Bu}$ çalışmanın amacı bu sendromlu fetüslerdeki fenotipik ve patolojik özellikleri belirlemektir.
\end{abstract}

Gereç ve Yöntem: Postmortem patolojik incelemede prune-belly sendromu bulunan altı fetüs incelendi. Sendromlu fetüslerde karakteristik özelliklerin yanı sıra ek anomaliler de değerlendirildi.

Bulgular: İncelenen fetüslerden biri kız, beşi erkek fetüstü. Fetüslerin gestasyonel yaşları 15-22 hafta arasında değişiyordu. Bütün olgularda mesaneden idrar çıkışını engelleyen üretral bir patoloji izlendi. Ayrıca mesane düz kasında atrofi ile birlikte mesane distansiyonu ve karın kaslarında atrofi ile birlikte abdominal distansiyon da bütün olgularda görüldü. Kripto-orşidizm, Potter yüzü, pes ekinovarus, pulmoner hipoplazi ve obstrüktif renal displazi diğer önemli anomaliler arasındaydi.

Sonuç: Prune-belly sendromunun patogenezi tartışmalıdır. $\mathrm{Bu}$ sendromun kalıtım yolunu, etiyolojisini ve patogenezini aydınlatmak için daha çok sayıda çalışmaya gereksinim vardır. Sendromda görülen anomalilerin patogenezini açıklamak için erken embriyonal dönemde, 2-3. haftalarda bilaminer ve trilaminer germ yapraklarını etkileyen faktörler dikkate alınmalıdır.

Anahtar Sözcükler: Prune-belly sendromu, Üretral obstrüksiyon, Üriner trakt anomalileri, Fetüs, Fetal patoloji

Correspondence: Davut ŞAHIN

Department of Pathology, Zeynep Kamil Women's and Children's Diseases Hospital, İSTANBUL, TURKEY

E-mail: davutpato@gmail.com Phone: +90 2163910680 


\section{INTRODUCTION}

Prune-belly syndrome has been recognized since 1839 with various names such as abdominal muscle defect, the EagleBarrett syndrome, and urethral obstruction malformation complex. It is seen once in every 35 to 50 thousand births and $95 \%$ of the cases are male (1). The syndrome takes its name from the changes in the abdominal skin. Extensive abdominal distension and tightness (the belly is distended, protuberant)arefrequentlyseen. Somecaseshave a distended abdomen and a lax, wrinkled appearance of abdominal skin (prune-like wrinkling). Common diagnostic features of all cases are various urethra pathologies preventing urine output from the bladder, bladder dilatation, absence of abdominal muscles and distended abdomen $(1,2)$. Urinary system defects such as posterior urethral valve, urethral stenosis, urethral atresia, prostate hypoplasia, marked atrophy of bladder muscles and bladder dilatation are frequently present. The most common urethra pathology is a posterior urethral valve (1). Most cases show bilateral undescended testes with marked Leydig cell hyperplasia, and partial or complete agenesis of the erectile tissues of the penis $(3,4)$. Ureteral dilatation (megaureters) due to urine collection in the bladder and increased pressure, cystic kidney changes, hydronephrosis and liver and thoracic organ deformations are frequently encountered (5). The abdominal skin can become thin and transparent due to the complete or partial absence of striated muscle in some cases and the visceral organs can be easily seen and palpated from the outside (6). Decreased urinary output from the bladder causes oligohidroamnios which can lead to pulmonary hypoplasia and a Potter face (2). Pes equinovarus (clubfoot) is the most common concurrent skeletal deformity while pulmonary hypoplasia is the most common visceral organ anomaly outside the urogenital system in this syndrome (7-9).

The exact cause of prune belly syndrome is not well known. The possible etiological factors are inheritance, intrauterine infections, mechanical causes, placenta previa, preeclampsia, anemia and parasitic infestations and young maternal age $(8,10)$. An autosomal recessive or X-linked inheritance is suggested $(4,11)$.

There are two theories regarding the pathogenesis. One is related to obstructive phenomena and states that the accumulation of urine in the bladder causing distention due to the anatomical stenosis of the urethra plays a central role in the development of all signs $(2,12)$. The second theory blames inadequate mesodermal development between 6 and 10 weeks of gestation stating that this defect simultaneously affects the bladder wall and abdominal wall muscles $\quad(2,3$, 12).
The risk of mortality is high in the intrauterine or early perinatal periods in affected cases. The pulmonary hypoplasia and end stage renal failure said to develop secondary to the lower urinary obstruction are responsible for about $60-75 \%$ of deaths (1).

\section{MATERIAL and METHOD}

Six fetuses with prune-belly syndrome were included in the study. Postmortem pathological investigation were performed and characteristic features including gestational age, pathologies in urethra, bladder and abdominal wall as well as other concurrent anomalies were evaluated.

\section{RESULTS}

Table I presents the characteristic features and concurrent anomalies of six fetuses with prune belly syndrome phenotype during postmortem pathological investigation. The maternal ages were $19,20,21,23,26$, and 31 with a mean value of 23.3 .

A urethral pathology that prevented urinary outflow from the bladder, marked bladder distension and abdominal distension were present in all cases (Figure 1, and 2). Cases 2-4 had abnormal histological structures in the proximal urethra showing several microscopic narrow channels and slit-like lumens lined by epithelium (Figure 3). Cases 3 and 5 had no proximal urethra lumen (agenesis). Case 5 showed total obstruction of the proximal urethra lumen and lack of penile erectile tissue development when compared with a normal male fetus of the same gestational week (Figure 4). In contrast to the other cases, Case 6 had a posterior urethral valve and pulmonary hypoplasia. There was no urinary outflow from the bladder due to the presence of lower urinary stenosis in Case 1 but marked postmortem changes and the formalin fixation prevented the dissection that could have provided detailed information. The testes were in the abdomen in all five male fetuses. The pes equinovarus deformity was present in Cases 3, 5 and 6 (Figure 2). There was atrophy of the bladder smooth muscle in all our cases when compared with the bladder of normal fetuses at the same gestational week. Case 3 had striated muscle tissue in the abdominal wall with swelling and necrosis of muscle cells (Figure 5). No striated muscle was found in the abdominal wall of the other cases. There was bilateral ureter dilatation, and bilateral obstructive renal dysplasia characterized by bilateral cystic glomerule and tubule dilatations, decreased number of nephrons, and increased interstitial mesenchymal tissue in Cases 3, 4, 5 and 6 (Figure 6). 
Table I: Characteristic features and concurrent anomalies of six cases with the Prune Belly Syndrome

\begin{tabular}{|c|c|c|c|c|c|}
\hline No & $\begin{array}{l}\text { IU* Week } \\
\text { / Gender }\end{array}$ & Urethra & Bladder & Abdominal wall & Other Findings \\
\hline 1 & $15 / \mathrm{M}$ & Stenosis & $\begin{array}{l}\text { Muscular atrophy } \\
\text { Dilatation }\end{array}$ & $\begin{array}{l}\text { Muscular agenesis } \\
\text { Abdominal distension }\end{array}$ & $\begin{array}{l}\text { Twin fetuses, male twin } \\
\text { normal } \\
\text { Stomach and liver pushed } \\
\text { towards thorax } \\
\text { Crypto-orchidism }\end{array}$ \\
\hline 2 & $16 / \mathrm{M}$ & $\begin{array}{l}\text { Fibrosis in the proximal } \\
\text { region } \\
\text { Stenosis }\end{array}$ & $\begin{array}{l}\text { Muscular atrophy } \\
\text { Dilatation }\end{array}$ & $\begin{array}{l}\text { Muscular agenesis } \\
\text { Abdominal distension }\end{array}$ & Crypto-orchidism \\
\hline 3 & $22 / F$ & $\begin{array}{l}\text { Fibrosis in the proximal } \\
\text { region } \\
\text { Total obstruction }\end{array}$ & $\begin{array}{l}\text { Muscular atrophy } \\
\text { Dilatation }\end{array}$ & $\begin{array}{l}\text { Muscular atrophy } \\
\text { Vacuolization and } \\
\text { degeneration of muscle } \\
\text { cells } \\
\text { Abdominal distension }\end{array}$ & $\begin{array}{l}\text { Potter face } \\
\text { Pes equinovarus } \\
\text { Ureter dilatation }(5 \mathrm{~mm}) \\
\text { Obstructive renal dysplasia }\end{array}$ \\
\hline 4 & $20 / \mathrm{M}$ & $\begin{array}{l}\text { Fibrosis in the proximal } \\
\text { region } \\
\text { Stenosis }\end{array}$ & $\begin{array}{l}\text { Muscular atrophy } \\
\text { Dilatation }\end{array}$ & $\begin{array}{l}\text { Muscular agenesis } \\
\text { Abdominal distension }\end{array}$ & $\begin{array}{l}\text { Penile erectile tissue agenesis, } \\
\text { Ureter dilatation ( } 4 \mathrm{~mm}) \text {, } \\
\text { Obstructive renal dysplasia, } \\
\text { Crypto-orchidism }\end{array}$ \\
\hline 5 & $20 / \mathrm{M}$ & $\begin{array}{l}\text { Fibrosis in the proximal } \\
\text { region } \\
\text { Total obstruction }\end{array}$ & $\begin{array}{l}\text { Muscular atrophy } \\
\text { Dilatation }\end{array}$ & $\begin{array}{l}\text { Muscular agenesis } \\
\text { Abdominal distension }\end{array}$ & $\begin{array}{l}\text { Pes equinovarus } \\
\text { Ureter dilatation ( } 5 \mathrm{~mm} \text { ) } \\
\text { Crypto-orchidism }\end{array}$ \\
\hline 6 & $20 / \mathrm{M}$ & Posterior urethral valve & $\begin{array}{l}\text { Muscular atrophy } \\
\text { Dilatation }\end{array}$ & $\begin{array}{l}\text { Muscular agenesis } \\
\text { Abdominal distension } \\
\text { Skin wrinkling }\end{array}$ & $\begin{array}{l}\text { Pulmonary hypoplasia } \\
\text { Pes equinovarus } \\
\text { Ureter dilatation }(6 \mathrm{~mm}) \\
\text { Crypto-orchidism } \\
\text { Phimosis in older brother }\end{array}$ \\
\hline
\end{tabular}

*: IU; Intrauterine

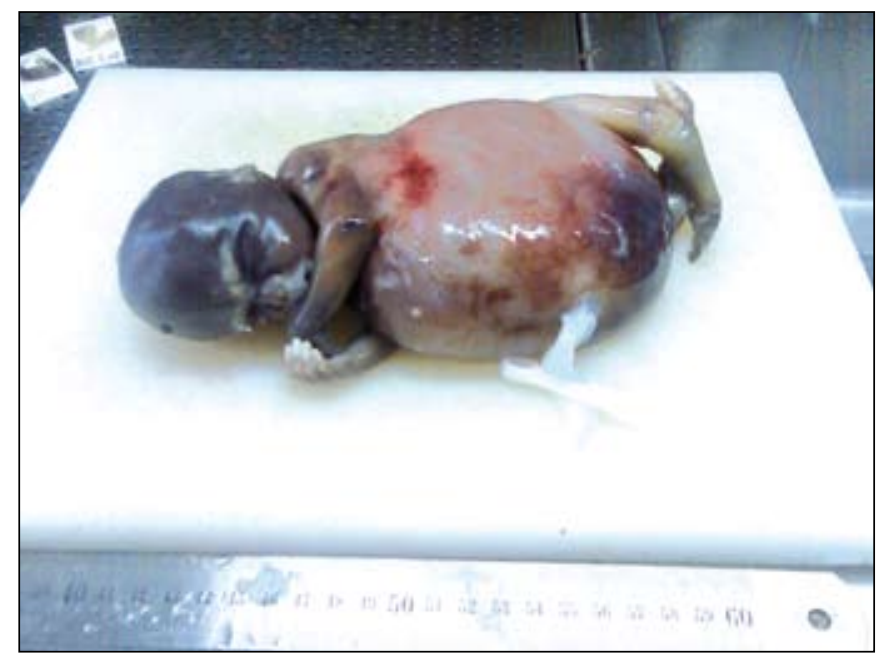

Figure 1: Abdominal distension and pes equinovarus deformity of the legs in the 22-week fetus.

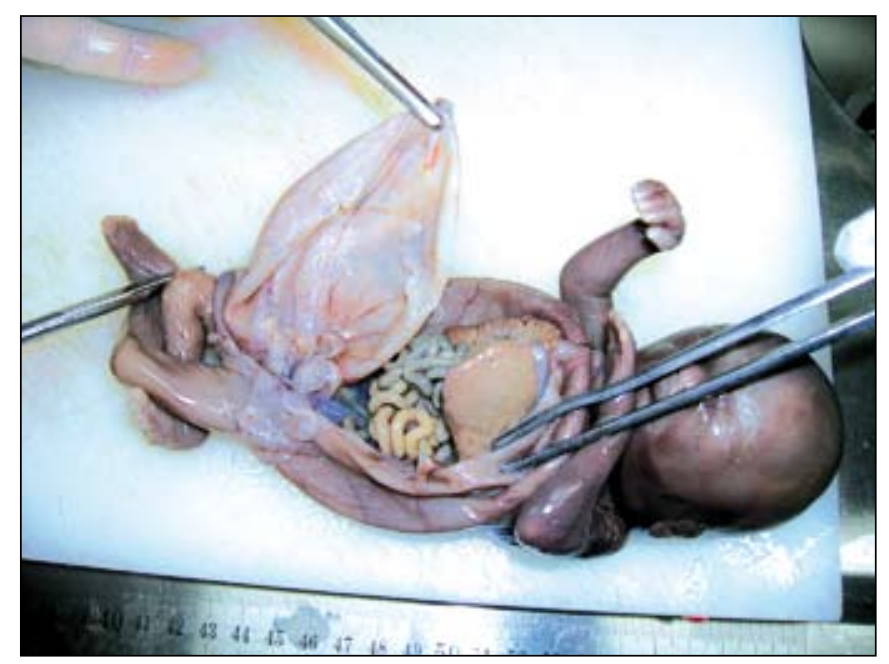

Figure 2: Markedly distended bladder in 20-week fetus. 


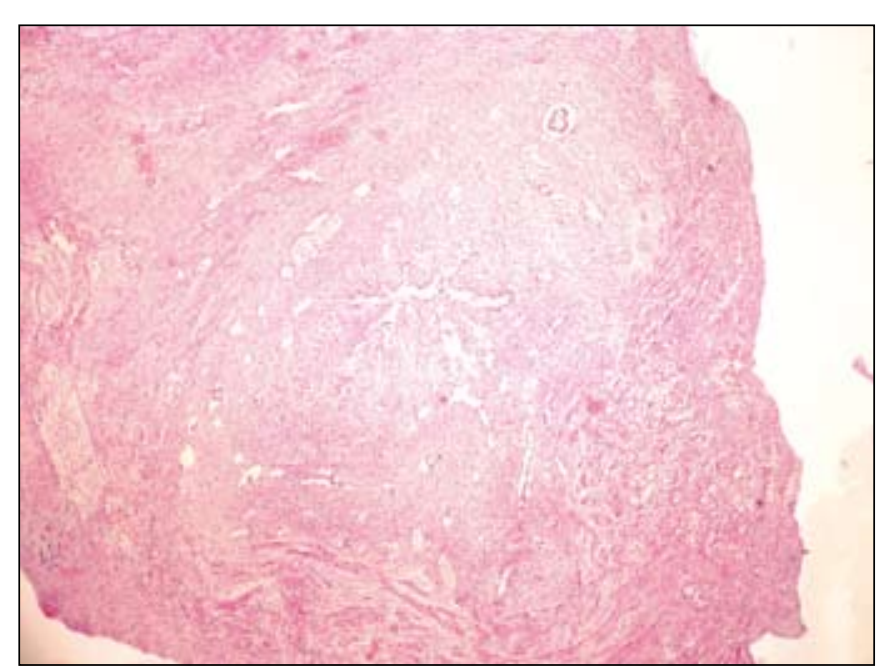

Figure 3: Microscopic appearance of the proximal urethra showing atresia in 20-week fetus (H\&E, x100).

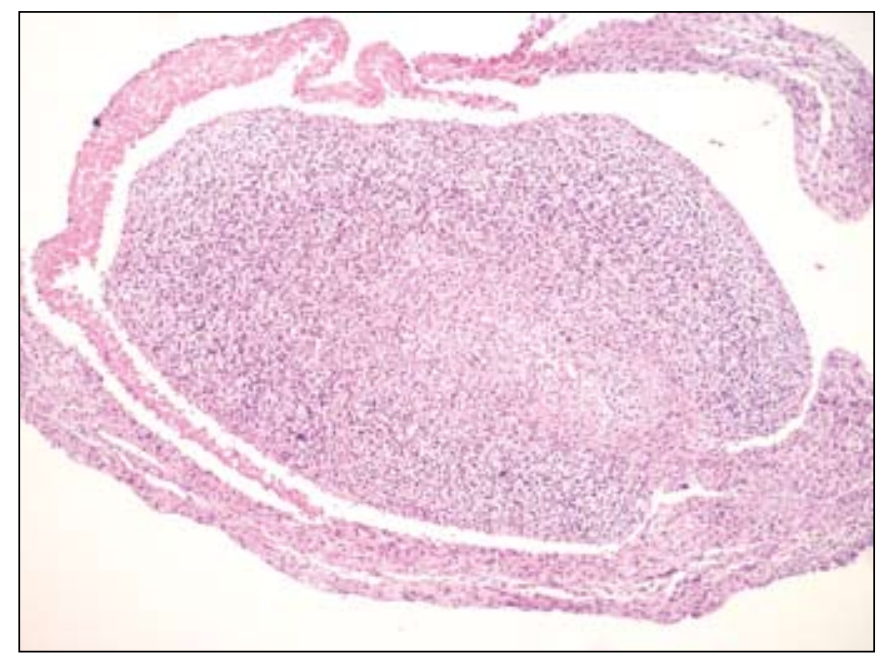

Figure 4: Agenesis of the urethral lumen and penile erectile tissues in cross-section of the penis in a 20 -week case (H\&E, x100).

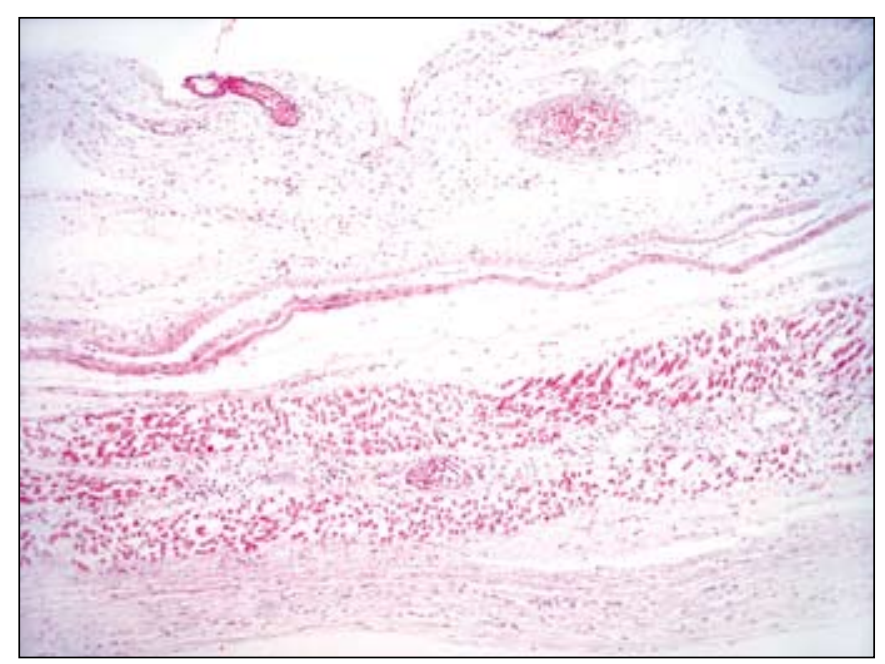

Figure 5: Atrophic striated muscle tissue in the full-layer section of the abdominal wall in a 22 -week case (H\&E, x100).

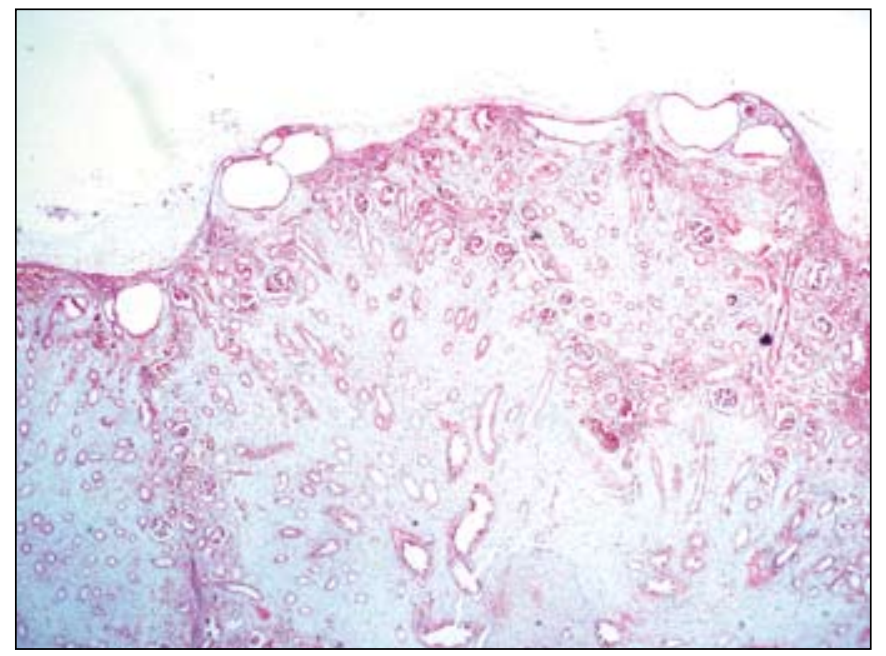

Figure 6: Obstructive renal dysplasia in the kidney of a 20-week fetus (H\&E, x40).

\section{DISCUSSION}

One of the main diagnostic characteristics of the prune belly syndromeisurethral pathologiesthat prevent urinaryoutflow from the bladder and the most common one is a posterior urethral valve. There was a urethral pathology preventing urinary outflow together with urinary collection in and dilatation of the bladder in allour cases. Case 6 had a posterior urethral valve. Cases 1,2 and 4 had urethral stenosis while 3 and 5 had total obstruction. The presence of pulmonary hypoplasia in many cases is explained as secondary to the oligohydramnios or due to the marked enlargement of the bladder causing pressure on the diaphragm and thoracic organs in the literature (2-12). Pulmonary hypoplasia was present in Case 6 but the diaphragm was in the normal anatomic position. Pulmonary hypoplasia may develop due to oligohydramnios or fetal maturation deficiency in the lungs. Megaureters and hydronephrosis are frequently reported in the kidneys with this syndrome (1). The ureters were markedly dilated and tortuous in four of our six cases while none had hydronephrosis. Hydronephrosis is dilatation of the renal pelvis and calices due to pathologies preventing outflow of urine together with progressive atrophy of the renal parenchyma (13). There was cystic nephronal changes and parenchymal atrophy in our cases and the lack of hydronephrosis may be explained by the termination of pregnancy at the 15 to 22 -week, early fetal period, as hydronephrosis is an atrophy that develops gradually secondary to urinary obstruction. Ureter dilation and obstructive renal dysplasia were not present in Cases 1 and 2 ( 15 and 16 weeks) but were present in the relatively older (20-22 weeks) Cases 3, 4, 5, and 6. This last condition 
may be accepted to indicate that the ureter and kidney pathologies develop secondary to the obstruction and that the severity will gradually increase. No skeletal muscle was seen in the abdominal wall of any case except Case 3 in which the gestational age was 22 weeks. When compared with the bladder of normal fetuses of the same age, all cases showed atrophy of the bladder smooth muscle tissue. The more marked and earlier disturbance of abdominal wall striated muscle compared to bladder muscle may indicate that the atrophy and aplasia in these cells does not develop secondary to bladder dilatation and pressure and is a primary anomaly or that bladder smooth muscle cells are more resistant to pressure than striated muscle (14). Other concurrent anomalies such as omphalocele, cardiac anomalies and hepatic artery aneurysm were also reported with this syndrome in the literature (15-17). The association of these anomalies with intra-abdominal pressure increase has not been fully demonstrated so it is difficult to explain the pathogenesis with the obstructive phenomena theory and they seem to support the second theory. The testes descend from the abdomen to the scrotum after 24 weeks (6). The fact that the testes were in the abdomen in all our five male cases may be explained by the cases being at the 15 to $22 \mathrm{nd}$ fetal weeks. Some authors ascribed the presence of undescended testes in many cases to the mechanical obstacle of the bladder or decreased intra-abdominal pressure (4). This last view needs clarification as the intraabdominal pressure is not low in the syndrome and is increased enough to cause aplasia of abdominal wall muscles and even deformation of thoracic organs (2). It is difficult to explain the prune belly phenotype, lack of abdominal striated muscle, and genital system abnormalities such as undescended testes, agenesis of penile erectile tissue and prostate hypoplasia with the mechanical pressure due to bladder dilatation and all these pathologies point towards inadequate mesodermal development that also affects the genital organs as stated by the second theory (14).

The inheritance of the syndrome can be autosomal recessive or X-linked, and $5 \%$ of the cases have been shown to develop in monozygotic male twin pregnancies where one fetus is affected and the other is not $(4,11)$. Our Case 1 had a male twin who developed normally. The presence in males in $95 \%$ of the cases, the development of renal failure, the presence of sensory deafness in some cases, and the presence of renal tubular and glomerular pathologies as in 4 of our cases are also seen in Alport syndrome, another X-linked syndrome (18). The presence of phimosis in the brother of our Case 6 is consistent with $\mathrm{X}$-linked inheritance.

Striated muscle, smooth muscle, and the urethra, kidneys, heart and vessels are of mesodermal origin (6). While it is possible to explain the pathogenesis of anomalies in organs of mesodermal origin such as the urinary system, abdominal wall striated muscle and the heart, it is difficult to explain the pathogenesis of anomalies in the lung and gastrointestinal system of endodermal origin and the nervous system (sensory deafness) of ectodermal origin that may also accompany the syndrome. More studies are needed on the inheritance, etiology and pathogenesis of the prune belly syndrome. It may be helpful to take into account factors that have a negative effect on the embryo on weeks 2-3 when bilaminar and trilaminar germ layers develop, much earlier than the 6-10th embryonal weeks, to explain the pathogenesis of these anomalies (6).

\section{ACKNOWLEDGEMENT}

We would like to thank all the technicians in our laboratory who followed-up and grouped all the fetuses with anomalies and supported us on technical issues and especially Ms. Nurhayat DAL.

\section{REFERENCES}

1. Bogart MM, Arnold HE, Greer KE: Prune-belly syndrome in two children and review of the literature. Pediatr Dermatol 2006, 23:342-345

2. Woods AG, Brandon DH: Prune-belly syndrome. A focused physical assessment. Adv Neonatal Care 2007, 7:132-143

3. Wigglesworth J.S: Texbook of Fetal and Perinatal Pathology, 2th ed. Massachusetts, Blackwell Science, 1998, 340, 1008

4. Enid G: Potter's Pathology of the Fetus, Infant and Child, 2th ed., Newyork, Mosby-Elsevier, 2007, 354-356

5. Gearhart JP, Lee BR, Partin AW, Epstein JI, Gosling JA: A quantitative histological evaluation of the dilated ureter of childhood. II: Ectopia, posterior urethral valfes and the Prune Belly syndrome. J Urol 1995, 153:172-176

6. Sadler T.W: Langman's Medical Embriology, 9th ed., Philadelphia, Lippincott co, 2004, 206-207, 333-334 339, 51,65

7. Druschel CM: A descriptive study of prune belly in New York State, 1983 to 1989. Arch Pediatr Adolesc Med 1995, 149:70-76

8. Salihu HM, Tchuinguem G, Aliyu MH, Kouam L: Prune belly syndrome and associated malformations. A 13-year experience from a developing country. West Indian Med J 2003, 52:281-284

9. Levin TL, Soghier L, Blitman NM, Vega-Rich C, Nafday S: Megacystis-microcolon-intestinal hypoperistalsis and prune belly: overlapping syndromes. Pediatr Radiol 2004, 34:995-998

10. Peshev ZV, Krusteva MB, Danev VH: A case of prune belly syndrome. Folia Med (Plovdiv) 2000, 42:66-88

11. Nouaili EB, Chaouachi S, Nouira F, Benmassoud I, Laabidi K, Chaouachi B, Marrakchi Z: Concordant posterior urethral valves in male monochorionic twins with secondary prune belly syndrome. Tunis Med 2008, 86:1086-1088

12. Volmar KE, Nguyen TC, Holcroft CJ, Blakemore KJ, Hutchins GM: Phimosis as a cause of the prune belly syndrome: comparison to a more common pattern of proximal penile urethra obstruction. Virchows Arch 2003, 442:169-172 
13. Kumar V, Abbas A, Fausto N: Robbins and Cotran Pathologic Basis of Disease, 7th ed., Philadelphia, Saunders- Elsevier, 2005, 1013

14. Volmar KE, Fritsch MK, Perlman EJ, Hutchins GM: Patterns of congenital lower urinary tract obstructive uropathy: relation to abnormal prostate and bladder development and the prune belly syndrome. Pediatr Dev Pathol 2001, 4:467-472

15. Alhawsawi AM, Aljiffry M, Walsh MJ, Peltekian K, Molinari M: Hepatic artery aneurysm associated with prune belly syndrome: a case report and review of the literature. J Surg Educ 2009, 66:4347

16. Al Harbi NN: Prune-belly anomalies in a girl with Down syndrome. Pediatr Nephrol 2003, 18:1191-1192

17. Sinico M, Touboul C, Haddad B, Encha-Razavi F, Paniel JB, Gicquel C, Gérard-Blanluet M: Giant omphalocele and "prunebelly" sequence as components of the Beckwith-Wiedemann syndrome. Am J Med Genet A 2004, 129A:198-200

18. Kumar V, Abbas A, Fausto N, Mitchell R: Robbins Basic Pathology. 8th ed., Saunders-Elsevier, International edition, 2007, 556-557 